2. Lenticles of material have been incorporated as englacial deposits, transported, and remoulded on "cores" of "drumloid" form, assuming a definite tectonic structure.

3. The tectonic structure has been preserved, and the beds have maintained their relative positions owing to an extremely slow rate of melting of the interstitial ice.

4. Hence the beds as now seen represent a glacial "pseudomorph " or "fossil glacier", the " hard parts" only remaining.

Analogous structure on a much greater scale has been investigated in America and Denmark. The structure has also been demonstrated experimentally by Professor W. J. Sollas, F.R.S. This type of investigation promises to lay the foundations of a new branch of geophysics by the combined labours of geologists in the field and physicists in the laboratory, as "Englacial material is analogous to the coloured material used by physicists to demonstrate in experimental physics the flow of viscous bodies". (Prof. A. N. Whitehead, F.R.S.)

\title{
CORRESPONDENCE.
}

\section{THE VARVED TERTIARY SEDIMENTS OF BURMA.}

SIR,- I am indebted to Dr. Ernst Antevs, of Harvard University, for calling my attention to the applicability of the adjective "varved" to the sediments showing seasonal rhythm described in my paper "Seasonal Rhythm in the Tertiary Sediments of Burma", Geological Magazine, November, 1925. De Geer proposed the word "varve" in 1912 as an international term for the distinctly marked annual deposit of a sediment regardless of its origin. The adjective "varved" has been used by Schuchert and the term "varvity" meaning "year-stratification" has been proposed by Kittredge. An important study of varved glacial sediments has been made by Antevs in his " Retreat of the Last Ice-Sheet in Eastern Canada", Canadian Geol. Surv., 1925. In view of the common occurrence of such banded sediments the term is a useful one.

CNIVERSITY OF LONDON.

L. Dedley Stamp.

10th October, 1926. 